\title{
THE COMPARISON OF VIKOR AND MAUT METHODS IN THE SELECTION OF USED CARS
}

\author{
Nurul Rahmadani ${ }^{1 *}$, Risnawati² \\ Information Management ${ }^{1}$; Computer System ${ }^{2}$ \\ Sekolah Tinggi Manajemen Informatika dan Komputer Royal \\ www.stmikroyal.ac.id \\ cloudyrara@gmail.com; rhisnawati176@gmail.com
}

(*) Corresponding Author

\begin{abstract}
Abstrak
Mobil bekas merupakan mobil yang sudah pernah digunakan orang lain. Memilih mobil bekas sesuai dengan kebutuhan pembeli sangatlah banyak pertimbangan. Pembeli mobil bekas menentukan pilihannya tentu berdasarkan pada beberapa kriteria. Kriteria dalam memilih mobil bekas antara lain transmisi, harga, kapasistas penumpang, kapasitas bagasi, tahun pembuatan, warna, dan kapasitas mesin. Kriteria tersebut merupakan pertimbangan pembeli dalam memilih mobil bekas karena tidaklah mudah bagi yang belum memahami kriteria dalam memilih mobil bekas. Penelitian ini bertujuan untuk membandingkan pemilihan mobil bekas dengan metode VIKOR (Vise Kriterijumska Optimizajica I Kompromisno Resenje) dan MAUT (Multi-Attribute Utility Theory). Metode VIKOR merupakan metode perangkingan dengan menggunakan indeks peringkat multikriteria berdasarkan ukuran tertentu dari kedekatan dengan solusi yang ideal. Sedangkan metode MAUT adalah metode multiatribut yang biasanya mengkombinasikan pengukuran atas biaya resiko dan keuntungan yang berbeda. Metode penelitian yang digunakan adalah penelitian deskriptif dengan pendekatan kuantitatif. Hasil dari penelitian ini dapat dilihat bahwa dengan menggunakan metode VIKOR dan MAUT memperoleh hasil yang sama yaitu A5 sebagai mobil bekas terpilih.
\end{abstract}

Kata kunci: Metode MAUT, Metode VIKOR, Mobil Bekas, Sistem Pendukung Keputusan

\begin{abstract}
A used car is a car that has been used by other people. Choosing a used car according to the needs of the buyer is very much a consideration. Used car buyers, of course, make their choices based on several criteria. The criteria for choosing a used car include transmission, price, passenger capacity, luggage capacity, year of manufacture, color, and engine capacity. These criteria are the buyer's consideration in choosing a used car because it is not easy for those who do not understand the criteria for choosing a used car. This research aims to compare the selection of used cars with the VIKOR method (Vise Kriterijumska Optimizajica I Kompromisno Resenje) and MAUT (Multi-Attribute Utility Theory). The VIKOR method is a ranking method using a multicriteria ranking index based on a certain measure of closeness to the ideal solution. Meanwhile, the MAUT method is a multi-attribute method that usually combines measurements of different risks and benefits. The research method used is descriptive research with a quantitative approach. The results of this study can be seen that using the VIKOR and MAUT methods obtained the same results, namely A5 as the selected used car.
\end{abstract}

Keywords: Decision Support System, MAUT Method, VIKOR Method, Used Car

\section{INTRODUCTION}

The car is a means of transportation that is considered to make human life easier. Since the discovery of this means of transportation, the movement of human life has changed to become faster and more dynamic (Nababan et al., 2018). Apart from daily necessities, activities and comfort from weather conditions, cars can carry a lot of passengers and are great for long trips. In addition, cars are also used for lifestyle and social status in the midst of society (Rizaldi \& Anggraeni, 2020).

Even though there are many car vehicles, some people find it difficult to get a new car due to economic factors, so they choose to buy a used car (Rizaldi \& Anggraeni, 2020). A used car is a car that has been used and then resold by the owner. A used car has a special sales area which is often called a showroom. The types of used cars sold in the showroom include SUV, MPV and sedans from various brands and years (Setiadi, 2019). The purpose of having a used car showroom is to 
provide facilities for vehicle needs at a more affordable price than new cars (Oktavia et al., 2016).

In purchasing a car, we can choose a new car or a used car. But the choice of a new car or a used car depends on the wishes of the buyer. And the condition of a used car is not the same as a new car, both in terms of the exterior, car paint, interior in the car, car engines, and so on. So between a new car and a used car cannot be equated because the condition of the new car is still $100 \%$, while used cars are under $100 \%$ condition (Oktaviani \& Putra, 2019).

Based on these problems, a decision support system is needed that can assist prospective buyers in making car purchases to make it easier and faster for prospective car buyers to determine the car to be purchased. Some methods can be applied in building a decision support system, including the VIKOR and MAUT methods. The VIKOR method is a ranking method using a multicriteria ranking index based on a certain measure of closeness to the ideal solution (Dwimas et al., 2019). This method is used to assist decision makers in getting the final decision (Sarumaha et al., 2018). Whereas the MAUT method can help convert some interests into numerical values on a scale of zero to one, to produce decisions (Maharani \& Sena, 2020).

In previous research, Nababan et al, used the VIKOR method in purchasing used cars, with 5 criteria, namely price, year of release, transmission, engine capacity, and passenger capacity. The results obtained in this study, the VIKOR method can assist buyers in making decisions in selection of used car (Nababan et al., 2018). In addition, Trisnani et al., Stated that the Selection of Outstanding Employees using the VIKOR method can be done so that they can quickly select high-achieving employees (Trisnani et al., 2018). Meanwhile, Sari \& Hayati conducted research in selecting boarding houses using the MAUT method. By applying the MAUT method in choosing a boarding house, you can objectively provide good boarding house recommendations (Sari \& Hayati, 2019). Furthermore, Maharani \& Nata also conducted research using the MAUT method, where the research compared the MFEP and MAUT methods in the selection of prospective participants in the national science olympiad. And the result of this study is that it has different results, namely the MFEP method produces A13 as the best participant, while the MAUT method produces A5 as the best participant (Maharani \& Nata, 2020).

Based on these researchs, it can be seen that the VIKOR and MAUT methods are methods that can help in making decisions. This study aims to solve the problem of buying a used car using the VIKOR and MAUT methods. The two methods were chosen because they were expected to produce the same results in the selection of used cars, as well as to assist potential buyers in selecting used cars according to the criteria they wanted.

\section{RESEARCH METHODS}

\section{VIKOR Method}

VIKOR (Vise Kriterijumska Optimizajica I Kompromisno Resenje) is one of the MCDM Techniques. VIKOR is based on the best solution obtained based on the closest ideal solution, then ranks it by comparing the distance to the ideal solution. This method aims to get the best solution with a profit rate (Azmi et al., 2018).

The calculation steps using the VIKOR method are as follows (Rahayu \& Rahmadani, 2020):

1. Normalizing using the following formula:

$$
R_{i j}=\left(\frac{x_{j^{+}}-x_{i j}}{x_{j^{+}}-x_{j^{-}}}\right)
$$

Where $R_{i j}$ and $X_{i j}(i=1,2,3, \ldots, m$ and $j=1,2,3, \ldots$, n) are the elements of the decision-making matrix (alternative i to criterion $\mathrm{j}$ ) and $x_{j}+$ is the highest element of criterion $\mathrm{j}, x_{j}$ - is the lowest element of criterion $\mathrm{j}$.

2. Calculate the values of $\mathrm{S}$ and $\mathrm{R}$ using the formula: $S_{i}=\sum_{j=1}^{n} W_{j}\left(\frac{x_{j^{+}}-x_{i j}}{x_{j^{+}}-x_{j^{-}}}\right)$

and

$$
R_{i}=\operatorname{Max}_{j}\left[W_{j}\left(\frac{x_{j^{+}}-x_{i j}}{x_{j^{+}}-x_{j^{-}}}\right)\right]
$$

Where $\mathrm{W}_{\mathrm{j}}$ is the weight of each criterion $\mathrm{j}$.

3. Determine the index value

$Q_{i}=\left[\frac{S_{i}-S^{+}}{S^{-}-S^{+}}\right] V+\left[\frac{R_{i}-R^{+}}{R^{-}-R^{+}}\right](1-V)$

Where $\mathrm{S}^{-}=\max \mathrm{S}_{\mathrm{i}}, \mathrm{S}^{+}=\min \mathrm{S}_{\mathrm{i}}$ and $\mathrm{R}^{-}=\operatorname{Max} \mathrm{R}_{\mathrm{i}}, \mathrm{R}^{+}$ $=$ Min $\mathrm{R}_{\mathrm{i}}$ and $\mathrm{V}=0.5$.

4. The ranking results are the result of ordering $S$, $\mathrm{R}, \mathrm{Q}$.

5. The best ranking alternative solution based on the minimum $\mathrm{Q}$ value becomes the best rank with the following conditions:

$Q\left(A^{(2)}\right)-Q\left(A^{(1)}\right) \geq D Q$.

Where $A^{(2)}=$ the alternative with the second order in the $\mathrm{Q}$ ranking and $A^{(1)}=$ the alternative with the best order in the $\mathrm{Q}$ ranking while $\mathrm{DQ}=$ 1 - $(\mathrm{m}-1)$, where $\mathrm{m}$ is the number of alternatives. Alternative $A^{(1)}$ must rank best on $\mathrm{S}$ and/or R.

\section{MAUT Method}

Multi-Attribute Utility Theory (MAUT) is part of the Multi-Attribute Decision Making (MADM) method (Adalı \& Işık, 2017). The MAUT 
method is defined as an algorithm with the approach of calculating the final evaluation ( $\mathrm{x}$ ) on an element value $\mathrm{x}$ which is commonly called by weight value by calculation addition with the weight value in dimensions or so-called with utility (Maharani \& Nata, 2020).

The steps for calculating the MAUT method are as follows (Ozdagoglu \& Cirkin, 2019):

1. Make a decision matrix

$$
D=\left[\begin{array}{cccc}
x_{11} & x_{12} & \cdots & x_{1 n} \\
x_{21} & x_{22} & \cdots & x_{2 n} \\
\cdots & \cdots & \cdots & \cdots \\
x_{m 1} & x_{m 2} & \cdots & x_{m n}
\end{array}\right]
$$

2. Compute the normalized performance scores for all values in the decision matrix.

If the benefit attribute, then it can be calculated by the Equation 7:

$y_{i j}=\frac{x_{i j}-\min _{i} x_{i j}}{\max _{i} x_{i j}-\min _{i} x_{i j}}$

If the attribute is cost, then it can be calculated by Equation 8:

$y_{i j}=\frac{\max _{i} x_{i j}-x_{i j}}{\max _{i} x_{i j}-\min _{i} x_{i j}}$

Based on these calculations, a normalized decision matrix such as Equation 9:

$$
Y=\left[\begin{array}{cccc}
y_{11} & y_{12} & \cdots & y_{1 n} \\
y_{21} & y_{22} & \cdots & y_{2 n} \\
\cdots & \cdots & \cdots & \cdots \\
y_{m 1} & y_{m 2} & \cdots & y_{m n}
\end{array}\right]
$$

3. Calculating the utility value of all alternatives in Equation 10:

$U_{i}=\sum_{j=1}^{n}\left(w_{j} * y_{i j}\right)$

Where the best alternative is the alternative that has the highest $U_{i}$ value.

\section{Types of research}

This type of research is a descriptive study with a quantitative approach. This study collected data to test hypotheses or answer questions in choosing a used car purchase.

\section{Time and Place of Research}

The research was conducted for six months from September 2020 to February 2021. The research location was conducted at Restu Mobil, Imam Bonjol street No. 324, Kisaran.

\section{Research Target / Subject}

The research target or subject is a used car showroom in Kisaran City, North Sumatra Province. To obtain this data, we conducted a field study at Restu Mobil.

\section{Procedure}

The procedure in this study can be seen in

Figure 1.

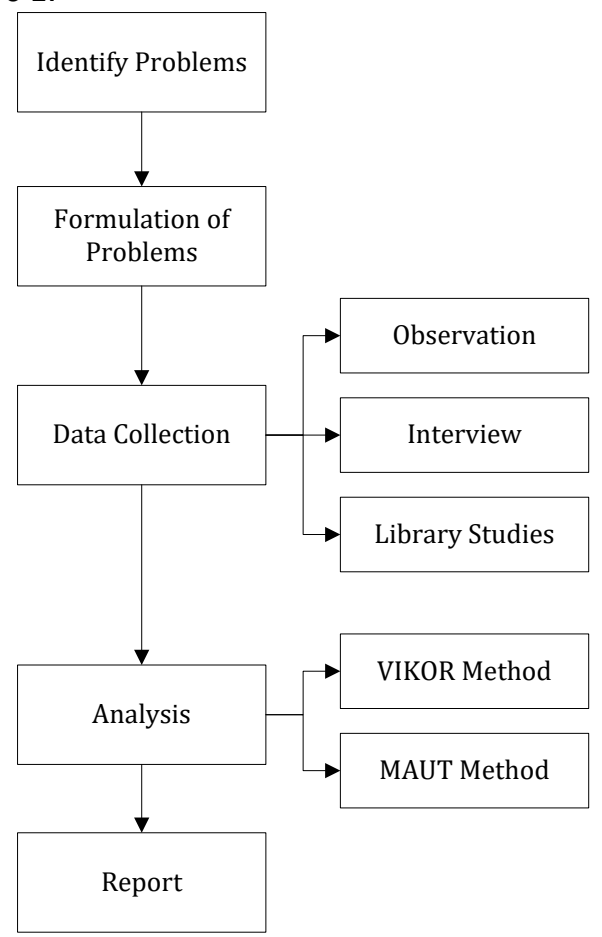

Figure 1. Research Procedure

\section{Data, Instruments, and Data Collection Techniques}

This study uses data sources including:

1. Primary Data

Primary data is obtained directly from used car showrooms.

2. Secondary data

Secondary data were collected from the study literature, journals, reports, and other information related to choosing a used car.

Where the two data are obtained by data collection methods, namely as follows:

1. Observations

Direct observation to find information about conditions directly at the Restu Mobil showroom.

2. Interview

Interview with Restu Mobil showroom owner regarding the condition of used cars in the showroom and the interests of used car buyers.

3. Study of literature

Gather good literature, data, information from scientific journals, books, and the internet related to choosing a used car.

\section{Data analysis technique}

In selecting a used car, there are 7 criteria that will be used in making a decision to choose a 
used car according to customer wishes. As for the alternatives used, it can be seen in Table 1 .

Table 1. Alternatives

\begin{tabular}{ccl}
\hline No. & Alternatif & Attribute Name \\
\hline 1 & $\mathrm{~A}_{1}$ & Daihatsu Sirion \\
\hline 2 & $\mathrm{~A}_{2}$ & Daihatsu Terios \\
\hline 3 & $\mathrm{~A}_{3}$ & Honda Jazz \\
\hline 4 & $\mathrm{~A}_{4}$ & Honda Jazz IDSI \\
\hline 5 & $\mathrm{~A}_{5}$ & Kijang Innova \\
\hline 6 & $\mathrm{~A}_{6}$ & Suzuki Ertiga \\
\hline 7 & $\mathrm{~A}_{7}$ & Toyota Agya \\
\hline 8 & $\mathrm{~A}_{8}$ & Toyota Avanza G \\
\hline 9 & $\mathrm{~A}_{9}$ & Toyota Yaris \\
\hline
\end{tabular}

Each criterion data has a different weight value, which is adjusted to its needs. For more details, it can be seen in table 2 .
Table 2. Criteria

\begin{tabular}{clcc}
\hline Criteria & \multicolumn{1}{c}{ Specific } & Weight & Type \\
\hline $\mathrm{C}_{1}$ & Transmission & $15 \%$ & Benefit \\
\hline $\mathrm{C}_{2}$ & Price & $20 \%$ & Cost \\
\hline $\mathrm{C}_{3}$ & $\begin{array}{l}\text { Passenger } \\
\text { Capacity }\end{array}$ & $16 \%$ & Benefit \\
\hline $\mathrm{C}_{4}$ & $\begin{array}{l}\text { Passenger } \\
\text { Capacity }\end{array}$ & $12 \%$ & Benefit \\
\hline $\mathrm{C}_{5}$ & Production year & $11 \%$ & Benefit \\
\hline $\mathrm{C}_{6}$ & Color & $8 \%$ & Benefit \\
\hline $\mathrm{C}_{7}$ & Engine Capacity & $18 \%$ & Benefit \\
\hline
\end{tabular}

Table 3 contains data on used cars that will be calculated using the VIKOR and MAUT methods.

Table 3. Used Car Data

\begin{tabular}{ccrccccc}
\hline \multirow{2}{*}{ Alternative } & \multicolumn{7}{c}{ Criteria } \\
\cline { 2 - 8 } & $\mathbf{C}_{1}$ & $\mathbf{C}_{2}$ & $\mathbf{C}_{3}$ & $\mathbf{C}_{\mathbf{4}}$ & $\mathbf{C}_{5}$ & $\mathbf{C}_{\mathbf{6}}$ & $\mathbf{C}_{\mathbf{7}}$ \\
\hline $\mathrm{A}_{1}$ & Automatic & 82 Juta & 5 Passengers & Small & 2012 & Black & $1300 \mathrm{cc}$ \\
\hline $\mathrm{A}_{2}$ & Automatic & 115 Juta & 5 Passengers & Big & 2013 & Black & $1500 \mathrm{cc}$ \\
\hline $\mathrm{A}_{3}$ & Manual & 102 Juta & 5 Passengers & Moderate & 2010 & Others & $1500 \mathrm{cc}$ \\
\hline $\mathrm{A}_{4}$ & Automatic & 72 Juta & 5 Passengers & Moderate & 2006 & Gray & $1500 \mathrm{cc}$ \\
\hline $\mathrm{A}_{5}$ & Manual & 130 Juta & 5 Passengers & Small & 2011 & Silver & $2000 \mathrm{cc}$ \\
\hline $\mathrm{A}_{6}$ & Automatic & 110 Juta & 5 Passengers & Big & 2014 & White & $1400 \mathrm{cc}$ \\
\hline $\mathrm{A}_{7}$ & Manual & 82,5 Juta & 5 Passengers & Moderate & 2013 & Silver & $1000 \mathrm{cc}$ \\
\hline $\mathrm{A}_{8}$ & Manual & 105 Juta & 5 Passengers & Small & 2012 & White & $1300 \mathrm{cc}$ \\
\hline $\mathrm{A}_{9}$ & Automatic & 99 Juta & 5 Passengers & Small & 2011 & Silver & $1500 \mathrm{cc}$ \\
\hline
\end{tabular}

To simplify the calculation process, Table 4 is created which contains the suitability rating of each alternative for each criterion.

Table 4. Suitability Rating of Each Alternative on Each Criterion

\begin{tabular}{crrrrrrr}
\hline Alter- & \multicolumn{7}{c}{ Criteria } \\
\cline { 2 - 8 } native & $\mathbf{C}_{\mathbf{1}}$ & $\mathbf{C}_{\boldsymbol{2}}$ & $\mathbf{C}_{\boldsymbol{3}}$ & $\mathbf{C}_{\boldsymbol{4}}$ & $\mathbf{C}_{\mathbf{5}}$ & $\mathbf{C}_{\boldsymbol{6}}$ & $\mathbf{C}_{\mathbf{7}}$ \\
\hline $\mathrm{A}_{1}$ & 25 & 82 & 5 & 10 & 2012 & 50 & 1300 \\
\hline $\mathrm{A}_{2}$ & 25 & 115 & 5 & 50 & 2013 & 50 & 1500 \\
\hline $\mathrm{A}_{3}$ & 50 & 102 & 5 & 30 & 2010 & 10 & 1500 \\
\hline $\mathrm{A}_{4}$ & 25 & 72 & 5 & 30 & 2006 & 20 & 1500 \\
\hline $\mathrm{A}_{5}$ & 50 & 130 & 8 & 10 & 2011 & 30 & 2000 \\
\hline $\mathrm{A}_{6}$ & 25 & 110 & 5 & 50 & 2014 & 40 & 1400 \\
\hline $\mathrm{A}_{7}$ & 50 & 82,5 & 5 & 30 & 2013 & 30 & 1000 \\
\hline $\mathrm{A}_{8}$ & 50 & 105 & 8 & 10 & 2012 & 40 & 1300 \\
\hline $\mathrm{A}_{9}$ & 25 & 99 & 5 & 10 & 2011 & 30 & 1500 \\
\hline Max & 50 & 130 & 8 & 50 & 2014 & 50 & 2000 \\
\hline Min & 25 & 72 & 5 & 10 & 2006 & 10 & 1000 \\
\hline Weight & 0.15 & 0.2 & 0.16 & 0.12 & 0.11 & 0.08 & 0.18 \\
\hline
\end{tabular}

RESULTS AND DISCUSSION

\section{Calculation of the VIKOR Method}

1. Perform normalization

Use Equation 1 for the calculation. And the results obtained from these calculations can be seen in the following matrix.

$$
\begin{aligned}
& R_{i j} \\
& \quad\left[\begin{array}{llllllll}
1,00 & 0,83 & 1,00 & 1,00 & 0,25 & 0,00 & 0,70 \\
1,00 & 0,26 & 1,00 & 0,00 & 0,13 & 0,00 & 0,50 \\
0,00 & 0,49 & 1,00 & 0,50 & 0,50 & 1,00 & 0,50 \\
1,00 & 1,00 & 1,00 & 0,50 & 1,00 & 0,75 & 0,50 \\
0,00 & 0,00 & 0,00 & 1,00 & 0,38 & 0,50 & 0,00 \\
1,00 & 0,35 & 1,00 & 0,00 & 0,00 & 0,25 & 0,60 \\
0,00 & 0,82 & 1,00 & 0,50 & 0,13 & 0,50 & 1,00 \\
0,00 & 0,43 & 0,00 & 1,00 & 0,25 & 0,25 & 0,70 \\
1,00 & 0,53 & 1,00 & 1,00 & 0,38 & 0,50 & 0,50
\end{array}\right]
\end{aligned}
$$

2. Calculating the values of $S$ and $R$

To calculate the value of $\mathrm{S}$, you can use Equation 2 , while the value of $\mathrm{R}$ can becalculated using Equation 3 so that the $\mathrm{S}$ and $\mathrm{R}$ values can be seen in Table 5. 
JURNAL RISET INFORMATIKA

Vol. 3, No. 2 March 2021
P-ISSN: 2656-1743 |E-ISSN: 2656-1735

DOI: https://doi.org/10.34288/jri.v3i2.193
Table 5. Value of S and R

\begin{tabular}{cccc}
\hline No. & Alternative & S & R \\
\hline 1 & $\mathrm{~A}_{1}$ & 0,749 & 0,166 \\
\hline 2 & $\mathrm{~A}_{2}$ & 0,465 & 0,160 \\
\hline 3 & $\mathrm{~A}_{3}$ & 0,542 & 0,160 \\
\hline 4 & $\mathrm{~A}_{4}$ & 0,830 & 0,200 \\
\hline 5 & $\mathrm{~A}_{5}$ & 0,201 & 0,120 \\
\hline 6 & $\mathrm{~A}_{6}$ & 0,507 & 0,160 \\
\hline 7 & $\mathrm{~A}_{7}$ & 0,618 & 0,180 \\
\hline 8 & $\mathrm{~A}_{8}$ & 0,380 & 0,126 \\
\hline 9 & $\mathrm{~A}_{9}$ & 0,708 & 0,160 \\
\hline
\end{tabular}

3. Determine the Index Value
$S^{-}=0,830$
$\mathrm{R}^{-}=0,200$
$\mathrm{S}^{+}=0,201$
$\mathrm{R}^{+}=0,120$

The next step is to calculate the value of $\mathrm{Q}_{\mathrm{i}}$ using Equation 4.

Where $\mathrm{V}=0.5$.

Table 6 contains the results of the alternative ranking from lowest to highest using the VIKOR method.

Table 6. The VIKOR Method Ranking Results

\begin{tabular}{ccc}
\hline Alternative & $\boldsymbol{Q}_{\boldsymbol{i}}$ & Ranking \\
\hline$A_{1}$ & 0,720 & 8 \\
\hline$A_{2}$ & 0,460 & 3 \\
\hline$A_{3}$ & 0,521 & 5 \\
\hline$A_{1}$ & 1,000 & 9 \\
\hline$A_{5}$ & 0,000 & 1 \\
\hline$A_{6}$ & 0,493 & 4 \\
\hline$A_{7}$ & 0,706 & 7 \\
\hline$A_{8}$ & 0,179 & 2 \\
\hline$A_{9}$ & 0,653 & 6 \\
\hline
\end{tabular}

From the table 6 of the ranking results, it is found that $A_{5}$ is the lowest value with a result of 0.000 so it was chosen as the selected used car as needed.

\section{Calculation of the MAUT Method}

1. Creating a Decision Matrix

D

$=\left[\begin{array}{rrrrrrr}\mathbf{2 5} & \mathbf{8 2} & \mathbf{5} & \mathbf{1 0} & \mathbf{2 0 1 2} & \mathbf{5 0} & \mathbf{1 3 0 0} \\ \mathbf{2 5} & \mathbf{1 1 5} & \mathbf{5} & \mathbf{5 0} & \mathbf{2 0 1 3} & \mathbf{5 0} & \mathbf{1 5 0 0} \\ \mathbf{5 0} & \mathbf{1 0 2} & \mathbf{5} & \mathbf{3 0} & \mathbf{2 0 1 0} & \mathbf{1 0} & \mathbf{1 5 0 0} \\ \mathbf{2 5} & \mathbf{7 2} & \mathbf{5} & \mathbf{3 0} & \mathbf{2 0 0 6} & \mathbf{2 0} & \mathbf{1 5 0 0} \\ \mathbf{5 0} & \mathbf{1 3 0} & \mathbf{8} & \mathbf{1 0} & \mathbf{2 0 1 1} & \mathbf{3 0} & \mathbf{2 0 0 0} \\ \mathbf{2 5} & \mathbf{1 1 0} & \mathbf{5} & \mathbf{5 0} & \mathbf{2 0 1 4} & \mathbf{4 0} & \mathbf{1 4 0 0} \\ \mathbf{5 0} & \mathbf{8 2 , 5} & \mathbf{5} & \mathbf{3 0} & \mathbf{2 0 1 3} & \mathbf{3 0} & \mathbf{1 0 0 0} \\ \mathbf{5 0} & \mathbf{1 0 5} & \mathbf{8} & \mathbf{1 0} & \mathbf{2 0 1 2} & \mathbf{4 0} & \mathbf{1 3 0 0} \\ \mathbf{2 5} & \mathbf{9 9} & \mathbf{5} & \mathbf{1 0} & \mathbf{2 0 1 1} & \mathbf{3 0} & \mathbf{1 5 0 0}\end{array}\right]$

The first stage in calculating the MAUT method is to create a decision matrix such as equation 6 . Where all the values of each criterion and alternatives in table 4 are made in the form of a matrix.

2. Calculating the Normalized Matrix
For the C2 criterion, namely price, we will use Equation 8, while the other criteria will use Equation 7 because of the types of benefits.

$$
\begin{aligned}
& {\left[\begin{array}{lllllll}
0,00 & 0,83 & 0,00 & 0,00 & 0,75 & 1,00 & 0,30 \\
0,00 & 0,26 & 0,00 & 1,00 & 0,88 & 1,00 & 0,50
\end{array}\right]} \\
& \begin{array}{llllllll}
0,00 & 0,26 & 0,00 & 1,00 & 0,88 & 1,00 & 0,50
\end{array} \\
& \begin{array}{llllllll}
1,00 & 0,49 & 0,00 & 0,50 & 0,50 & 0,00 & 0,50
\end{array} \\
& \begin{array}{llllllll}
0,00 & 1,00 & 0,00 & 0,50 & 0,00 & 0,25 & 0,50
\end{array} \\
& Y=\begin{array}{llllllll}
1,00 & 0,00 & 1,00 & 0,00 & 0,63 & 0,50 & 1,00
\end{array} \\
& \begin{array}{llllllll}
0,00 & 0,35 & 0,00 & 1,00 & 1,00 & 0,75 & 0,40
\end{array} \\
& \begin{array}{lllllll}
1,00 & 0,82 & 0,00 & 0,50 & 0,88 & 0,50 & 0,00
\end{array} \\
& \begin{array}{llllllll}
1,00 & 0,43 & 1,00 & 0,00 & 0,75 & 0,75 & 0,30
\end{array} \\
& {\left[\begin{array}{lllllll}
0,00 & 0,53 & 0,00 & 0,00 & 0,63 & 0,50 & 0,50
\end{array}\right.}
\end{aligned}
$$

After being calculated, the results obtained from these calculations can be made in the form of a normalized decision matrix by Equation 9 .

3. Calculating the Value of Utility

Perform calculations using Equation 10 to get the final result of the MAUT method, so that it can produce a ranking as in Table 7.

Table 7. The MAUT Method Ranking Results

\begin{tabular}{ccc}
\hline Alternative & $\boldsymbol{U}_{\boldsymbol{i}}$ & Ranking \\
\hline$A_{1}$ & 0,382 & 7 \\
\hline$A_{2}$ & 0,438 & 5 \\
\hline$A_{3}$ & 0,452 & 4 \\
\hline$A_{1}$ & 0,370 & 8 \\
\hline$A_{5}$ & 0,599 & 1 \\
\hline$A_{6}$ & 0,431 & 6 \\
\hline$A_{7}$ & 0,510 & 3 \\
\hline$A_{8}$ & 0,593 & 2 \\
\hline$A_{9}$ & 0,306 & 9 \\
\hline
\end{tabular}

From table 7, the decision with the highest value can be taken, namely $A_{5}$ as the selected used car.

\section{CONCLUSIONS AND SUGGESTIONS}

\section{Conclusion}

Based on the research that has been carried out by comparing the VIKOR and MAUT methods in selecting used cars, it can be concluded that the two methods have the same results in the selection of used cars, namely the A5 alternative. However, for some of the other rankings there are differences in the results. This is because the method used is different, where the VIKOR method is an MCDM method with a compromise ranking idea, while the MAUT method is an MADM method with a final evaluation scheme with weights and values relevant to the alternative. In addition, the MAUT method uses calculations based on types, namely benefits and costs, while the VIKOR method does not use it, so it has different results for its ranking. 


\section{Suggestion}

To get maximum results, you can make comparisons with the same method techniques. In addition, you can also add other criteria in selection of used car.

\section{REFERENCES}

Adalı, E. A., \& Işık, A. T. (2017). Critic and Maut Methods for the Contract Manufacturer Selection Problem. European Journal of Multidisciplinary Studies, 5(1), 93. https://doi.org/10.26417/ejms.v5i1.p93101

Azmi, D. T., Barus, H., Marbun, F. L., Ginting, G., \& Hasibuan, N. A. (2018). Perancangan Sistem Pendukung Keputusan Penerimaan Siswa Baru Dengan Menerapkan Metode VIKOR. Jurnal Riset Komputer, 5(2), 124-129.

Dwimas, H., Sumantri, Y., \& Santoso, P. B. (2019). Integration of Analytical Hierarchy Process and Vikor To Achieve a Sustainable Manufacturing System. Journal of Engineering and Management in Industrial System, 7(2), 110-119.

https://doi.org/10.21776/ub.jemis.2019.007 .02 .6

Maharani, D., \& Nata, A. (2020). PERBANDINGAN METODE MFEP DAN MAUT DALAM SELEKSI CALON PESERTA OLIMPIADE SAINS NASIONAL (OSN). JURTEKSI (Jurnal Teknologi Dan Sistem Informasi), VI(3), 247-252. https://doi.org/https://doi.org/10.33330/ju rteksi.v6i3.793

Maharani, D., \& Sena, M. D. (2020). The MFEP and MAUT Methods in Selecting The Best Employees. Proceeding International Conference on Social, Sciences and Information Technology, $19-26$. https://doi.org/https://doi.org/10.33330/ic ossit.v1i1.822

Nababan, D. R., Lestari, P., \& Rizka, N. (2018). Sistem Pendukung Keputusan Pembelian Mobil Bekas Dengan Menerapkan Metode Vikor. Seminar Nasional Sains \& Teknologi Informasi (SENSASI), 552-559.

Oktavia, Y., Susilo, B., \& Efendi, R. (2016). Rekomendasi Pembelian Mobil Bekas Menggunakan Metode Multi-Factor Evaluation Process ( MFEP) dan Basis Data Fuzzy Tahani.
$140-151$

Oktaviani, V., \& Putra, Z. F. F. (2019). Decision Support System To Help Buyers Determine The Quality Of Used Car Purchases With The Web-Based Simple Additive Weighting (SAW) Method. JOINCS (Journal of Informatics, Network, and Computer Science), 2, 1-6. https://doi.org/10.21070/joincs.v2i0.709

Ozdagoglu, A., \& Cirkin, E. (2019). Electronic Device Selection in Industrial Products and Machinery Industry: Comparative Analysis With Ocra and Maut Method. International Journal of Contemporary Economics and Administrative Sciences, 9(1), 119-134.

Rahayu, E., \& Rahmadani, N. (2020). The Comparison of WASPAS and VIKOR Methods in Assessment of Lecturer Performance. Proceeding International Conference on Social, Sciences and Information Technology, 1(1), 110.

https://jurnal.stmikroyal.ac.id/index.php/IC oSSIT/article/view/686

Rizaldi, \& Anggraeni, D. (2020). Decision Support System Selection Used Car Using The Fuzzy. Proceeding International Conference on Social, Sciences and Information Technology, 1(1), 235-242.

https://doi.org/https://doi.org/10.33330/ic ossit.v1i1.729

Sari, R. N., \& Hayati, R. S. (2019). Penerapan Metode Multi Attribute Utility Theory (MAUT) Dalam Pemilihan Rumah Kost. J-SAKTI (Jurnal Sains Komputer Dan Informatika), 3(2), 243. https://doi.org/10.30645/j-sakti.v3i2.144

Sarumaha, N. I., Simanungkalit, M., \& Damanik, M. (2018). Sistem Pendukung Keputusan Penerimaan Pegawai Baru Menerapkan Metode VIKOR dan MOORA. Seminar Nasional Sains \& Teknologi Dan Informasi(SENSASI), ISBN: 978-602-52720-0-4, 193-214.

Setiadi, I. (2019). Sistem Pendukung Keputusan Pemilihan Mobil Bekas. Jurnal String, 3(3), 247-257.

Trisnani, A. A., Anwar, D. U., Ramadhani, W., Manurung, M. M., \& Siahaan, A. P. U. (2018). Sistem Pendukung Keputusan Pemilihan Karyawan Berprestasi Menerapkan Metode Vise Kriterijumska Optimizajica I Kompromisno Resenje (VIKOR). JURIKOM (Jurnal Riset Komputer), Vol. 5 No.(2), 85-90. 